\title{
Sensitivity analysis of CROPGRO- cotton model to intra-seasonal climatic variability in middle Gujarat
}

\author{
D. D. PATIL,VYAS PANDEY, VIPUL KAPADIA ${ }^{1}$ and A. C. SADHU ${ }^{1}$ \\ Department of Agricultural Meteorology, 'Regional Research Station, \\ Anand Agricultural University, Anand 388110, Gujarat \\ Email:tornekardeepak@gmail.com
}

\begin{abstract}
The CROPGRO-Cotton model was first calibrated and validated with the six years (2011-12 to 2016-17) of experimental data collected at Regional Research Station, A.A.U., Anand for two cultivars of cotton (DCH 32 and G. Cot. Hy. 102) to study the effect of intra-seasonal climatic variability on seed cotton yield. The model sensitivity analysis was carried out by incremental change in climatic parameters (maximum and minimum temperature from $-3^{\circ}$ to $+3^{\circ} \mathrm{C}$ ) and rainfall $(-25 \%$ to $+25 \%)$. Results revealed that elevated temperature had negative effect on seed cotton yield and reduced temperature had positive effect on seed cotton yield. The varieties $\mathrm{DCH} 32$ was slightly less affected by the temperature variation than G. Cot. Hy. 102. Temperature variation during October to December was found to have maximum effect on cotton crop. The effect of minimum temperature on seed cotton yield was more than that observed with maximum temperature.Cotton crop was affected more by variation in rainfall during September in comparison to that of July and August.
\end{abstract}

Keywords : Intra-seasonal temperature, rainfall, CROPGRO- cotton

Cotton (Gossypium hirsutum L.) is one of the major cash crops of India, popularly known as "white gold and "King of fibres for its role in the national economy in terms of foreign exchange earnings and employment generation. It is the world's leading source of natural textile fibre and fifth largest oilseeds crop which covers forty per cent of the global textile need (APTMA, 2012) and 3.3 per cent of edible oil (FAS, 2014) respectively. This crop provides livelihood to sixty million people in India by way of support of agriculture, processing and textiles and it contributes to twenty nine per cent of the national GDP (Khadi, 2010). India has the credit of the largest area under cotton (126.55 lakh ha) and ranks second in cotton production (400 lakh bales) during 2014-15 (Nagender, 2017). However, the productivity of seed cotton in India is $537 \mathrm{~kg} \mathrm{ha}^{-1}$ which is below the world average of $790 \mathrm{~kg} \mathrm{ha}^{-1}$.

Climate affects crop growth interactively, sometimes resulting in unexpected responses to prevailing conditions. Many factors, such as length of the growing season, climate (including solar radiation, temperature, light, wind, rainfall and dew), cultivar, availability of nutrients and soil moisture, pests and cultural practices affect cotton growth (El-Zik, 1980). Temperature is also a primary factor controlling rates of plant growth and development. Hodges et al. (1993) found that the optimum temperature for cotton stem and leaf growth, seedling development and fruiting was almost $30^{\circ} \mathrm{C}$, with fruit retention decreasing rapidly as the time of exposure to $40^{\circ} \mathrm{C}$ increased. Reddy et al. (1999) also observed that high temperatures produce bud shedding in cotton and they further reported that temperature regimes alter boll development, boll size and the maturity period both decreased as the temperature increased.

The CROPGRO-Cotton model is a member of the CROPGRO group of models (Hoogenboom, 1992) in DSSAT. Crop models have been described as a "quantitative schemes for predicting the growth, development and yield of a crop, given a set of genetic coefficients and relevant environmental variables" (Monteith, 1996). Models can be used to predict crop growth, development and yield as a function of soil, climate, weather, and crop management conditions. Crop simulation models have been used to study the effect of intra-seasonal variation in temperature on yield of wheat in India (Sandhu et al., 2016). Patil et al. (2018 a \& b) have reported the effect of intra-seasonal variation of temperature on tuber yield of potato and seed yield of pigeonpea in Gujarat using DSSAT group of models. Temperature is a primary environmental factor controlling growth and developmental rates of plants, yet little specific information is available regarding cotton (Gossypium hirsutum L.) responses to temperature. Information covering a wide range 
of temperatures would be useful for predicting both developmental and growth rates in cotton. The objective of this study was to assess the effect of intra-seasonal climatic variability on seed cotton yield of cotton in middle Gujarat using CROPGRO- cotton model.

\section{MATERIALS AND METHODS}

\section{Experimental and weather data}

The data collected during six years of experimentation (2011-12 to 2016-17) on two cultivars ( $\mathrm{V}_{1}$ - DCH 32 and, $\mathrm{V}_{2}$ G. Cot. Hy. 102) of cotton was obtained from Regional Research Station, Anand Agricultural University, Anand. Seeds were sown on the onset of monsoon with spacing of
Table 1: Mean seed cotton yield $\left(\mathrm{kg} \mathrm{ha}^{-1}\right)$ of cotton of two varieties during six years (2011-12 to 2016-17)

\begin{tabular}{lrr}
\hline Year & $\mathrm{V}_{1}:($ DCH 32) & $\mathrm{V}_{2}:($ G. Cot. Hy. 102) \\
\hline $2011-12$ & 1287 & 941 \\
$2012-13$ & 394 & 803 \\
$2013-14$ & 1115 & 1152 \\
$2014-15$ & 444 & 414 \\
$2015-16$ & 1506 & 983 \\
$2016-17$ & 1337 & 996 \\
$2017-18$ & 1014 & 882 \\
\hline
\end{tabular}

Table 2: Genotype coefficients of cotton cultivars DCH - 32 and G Cot. Hy. 102

\begin{tabular}{|c|c|c|c|}
\hline \multirow[t]{2}{*}{ Parameters } & \multirow[t]{2}{*}{ Description of parameters } & \multicolumn{2}{|c|}{ Genotype coefficients } \\
\hline & & DCH - 32 & G.Cot.Hy. 102 \\
\hline CSDL & $\begin{array}{l}\text { Critical Short Day Length below which reproductive development } \\
\text { progresses with no day length effect (for short day plants) (hour) }\end{array}$ & 23 & 23 \\
\hline PPSEN & $\begin{array}{l}\text { Slope of the relative response of development to photoperiod } \\
\text { with time (Positive for short day plants) ( } 1 \text { /hour) }\end{array}$ & 0.01 & 0.01 \\
\hline EM-FL & $\begin{array}{l}\text { Time between plant emergence and flower appearance (R1) } \\
\text { (photothermal days) }\end{array}$ & 42 & 40 \\
\hline FL-SH & Time between first flower and first pod (R3) (photothermal days) & 13 & 15 \\
\hline FL-SD & Time between first flower and first seed (R5) (photothermal days) & 18 & 21 \\
\hline SD-PM & $\begin{array}{l}\text { Time between first seed (R5) and physiological maturity (R7) } \\
\text { (photothermal days) }\end{array}$ & 55 & 51 \\
\hline FL-LF & $\begin{array}{l}\text { Time between first flower (R1) and end of leaf expansion } \\
\text { (photothermal days) }\end{array}$ & 70 & 67 \\
\hline LFMAX & $\begin{array}{l}\text { Maximum leaf photosynthesis rate at } 300 \mathrm{C}, 350 \mathrm{vpm} \mathrm{CO}_{2} \text { and high light } \\
\left(\mathrm{mg} \mathrm{CO}_{2} / \mathrm{m}^{2}-\mathrm{s}\right)\end{array}$ & 1.3 & 1.3 \\
\hline SLAVR & Specific leaf area of cultivar under standard growth conditions $\left(\mathrm{cm}^{2} / \mathrm{g}\right)$ & 390 & 390 \\
\hline SIZLE & Maximum size of full leaf(three leaflets) $\left(\mathrm{cm}^{2}\right)$ & 390 & 390 \\
\hline XFRT & Maximum fraction of daily growth that is partitioned to seed + shell & 0.75 & 0.75 \\
\hline WTPSD & Maximum weight per seed $(\mathrm{g})$ & 0.18 & 0.18 \\
\hline SFDUR & $\begin{array}{l}\text { Seed filling duration for pod cohort at standard growth conditions } \\
\text { (photothermal days) }\end{array}$ & 35 & 35 \\
\hline SDPDV & Average seed per pod under standard growing conditions (\#/pod) & 27 & 27 \\
\hline PODUR & $\begin{array}{l}\text { Time required for cultivar to reach final pod load under optimal } \\
\text { conditions (photothermal days) }\end{array}$ & 10 & 10 \\
\hline THRSH & Threshing percentage. The maxi. ratio of seed [seed/(seed+shell)] & 79 & 75 \\
\hline SDPRO & Fraction protein in seeds $[\mathrm{g}($ protein $) / \mathrm{g}($ seed $)]$ & 0.141 & 0.151 \\
\hline SDLIP & Fraction oil in seed [g(oil)/g(seed)] & 0.12 & 0.12 \\
\hline
\end{tabular}



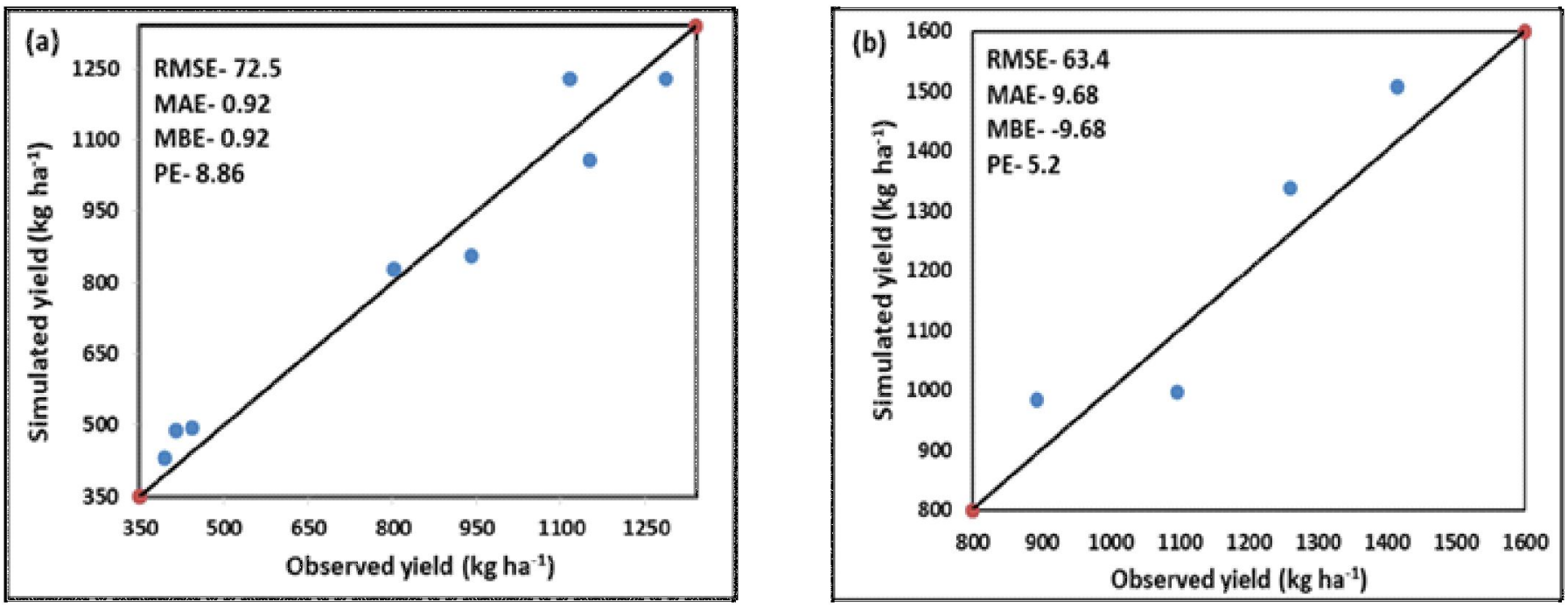

Fig. 1: Observed and simulated seed cotton yield of cotton during (a) calibration period (2011 to 2014) and (b) validation (2015 and 2016) of CROPGRO-cotton model

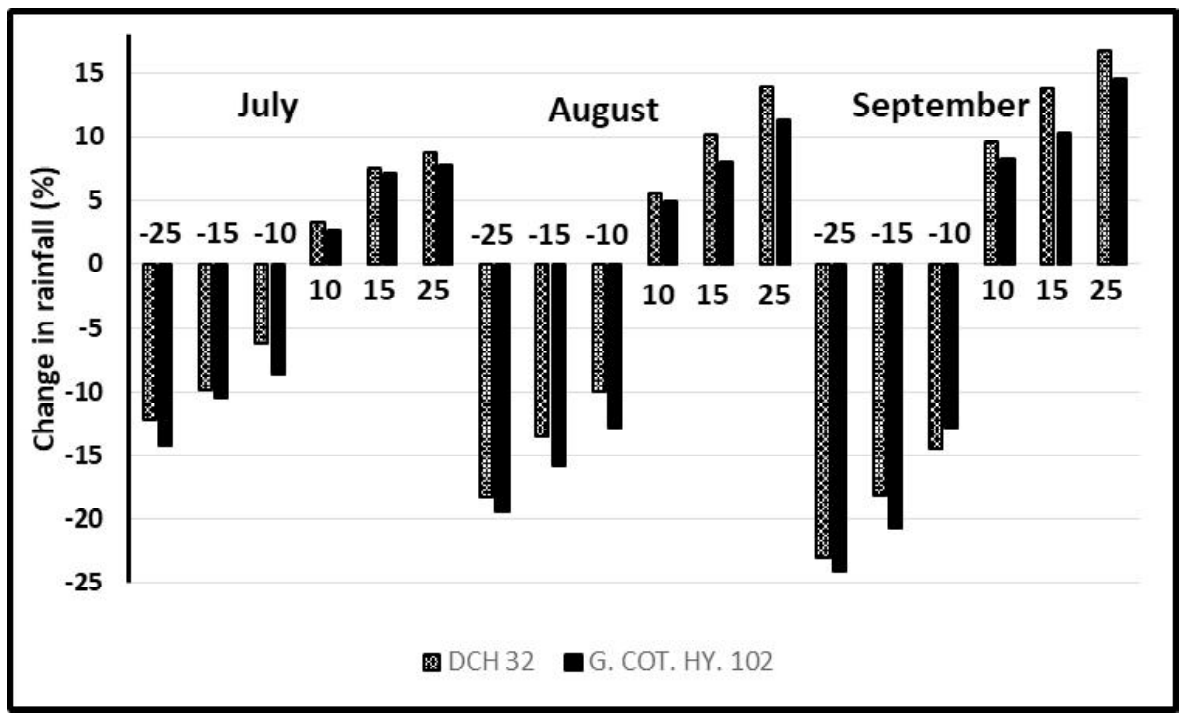

Fig. 2: Effect of intra-seasonal variation of rainfall on seed cotton yield

$120 \mathrm{~cm} \times 45 \mathrm{~cm}$ and with recommended dose of fertilizer 240:40:25 NPK kg ha-1 during all the growing seasons. The soil type of the experimental site was sandy loam a true representative soil of the region. Irrigation was applied during dry spell and plant protection measures were followed as per the scheduled package of practices. The corresponding weather data was obtained from Department of Agricultural Meteorology, Anand Agricultural University, Anand.

\section{CROPGRO- cotton model}

The DSSAT family of CROPGRO- cotton model (Hoogenboom et al., 2004) was employed to simulate seed cotton yield of cotton crop. The model was calibrated and validated for two cultivars with the experimental data. The model was calibrated with the four years (2011-12 to 201415) of experimental data and validated with two years (2015-16 and 2016-17) data. The cultivar coefficients were estimated by repeated iteration's by running the GLUE coefficient estimator until a close match between simulated and observed seed cotton yield was obtained (Table 2).

The model performance was evaluated using test criteria viz. root mean square error (RMSE), mean absolute error (MAE), mean bias error (MBE), coefficient of determination $\left(\mathrm{R}^{2}\right)$ and per cent error $(\mathrm{PE})$ and calculated as reported by Patil and Patel (2017).

\section{Impact studies}

The validated CROPGRO-cotton model was used to 
Table 3: Intra seasonal effects of maximum and minimum temperature on seed cotton yield in different months

\begin{tabular}{|c|c|c|c|c|c|}
\hline \multirow[t]{2}{*}{ Months } & \multirow{2}{*}{$\begin{array}{l}\text { Change in } \\
\text { temperature }\end{array}$} & \multicolumn{2}{|c|}{ Maximum temperature } & \multicolumn{2}{|c|}{ Minimum temperature } \\
\hline & & DCH 32 & G. COT. HY. 102 & DCH 32 & G. COT. HY. 102 \\
\hline \multirow[t]{6}{*}{ July } & -3 & 4.7 & 5.1 & 4.4 & 4.6 \\
\hline & -2 & 3.1 & 2.8 & 2.6 & 2.7 \\
\hline & -1 & 1.2 & 1.4 & 0.9 & 1.1 \\
\hline & 1 & -1.7 & -2.1 & -1.5 & -1.8 \\
\hline & 2 & -3.5 & -3.9 & -3.3 & -3.7 \\
\hline & 3 & -5.3 & -5.5 & -4.6 & -5.0 \\
\hline \multirow[t]{6}{*}{ August } & -3 & 9.6 & 10.2 & 9.0 & 9.3 \\
\hline & -2 & 6.2 & 6.6 & 5.6 & 6.3 \\
\hline & -1 & 2.2 & 2.1 & 1.9 & 2.1 \\
\hline & 1 & -2.5 & -3.0 & -2.3 & -2.4 \\
\hline & 2 & -5.1 & -5.6 & -4.6 & -5.1 \\
\hline & 3 & -7.8 & -8.3 & -7.1 & -7.6 \\
\hline \multirow[t]{6}{*}{ September } & -3 & 10.7 & 10.9 & 9.9 & 10.2 \\
\hline & -2 & 8.6 & 8.5 & 8.0 & 8.2 \\
\hline & -1 & 4.2 & 4.0 & 3.7 & 3.7 \\
\hline & 1 & -4.5 & -4.1 & -4.3 & -4.6 \\
\hline & 2 & -8.9 & -7.6 & -8.4 & -8.1 \\
\hline & 3 & -11.7 & -12.1 & -11.2 & -11.0 \\
\hline \multirow[t]{6}{*}{ October } & -3 & 9.3 & 9.9 & 8.8 & 9.4 \\
\hline & -2 & 8.2 & 8.5 & 7.9 & 8.0 \\
\hline & -1 & 6.3 & 6.5 & 5.6 & 5.9 \\
\hline & 1 & -5.9 & -6.1 & -5.8 & -5.9 \\
\hline & 2 & -9.4 & -10.1 & -9.3 & -9.9 \\
\hline & 3 & -12.7 & -12.3 & -11.5 & -11.6 \\
\hline \multirow[t]{6}{*}{ November } & -3 & 9.5 & 9.8 & 9.2 & 9.6 \\
\hline & -2 & 8.6 & 8.2 & 8.6 & 8.1 \\
\hline & -1 & 6.5 & 6.1 & 6.2 & 6.6 \\
\hline & 1 & -6.1 & -6.2 & -5.9 & -6.0 \\
\hline & 2 & -9.8 & -9.9 & -9.6 & -9.3 \\
\hline & 3 & -12.3 & -12.5 & -11.5 & -11.1 \\
\hline \multirow[t]{6}{*}{ December } & -3 & 9.8 & 9.7 & 9.5 & 9.7 \\
\hline & -2 & 8.0 & 8.6 & 7.2 & 7.8 \\
\hline & -1 & 5.9 & 6.3 & 5.4 & 5.8 \\
\hline & 1 & -6.5 & -6.7 & -6.2 & -6.1 \\
\hline & 2 & -9.6 & -9.5 & -9.4 & -9.6 \\
\hline & 3 & -13.1 & -11.3 & -12.1 & -11.8 \\
\hline \multirow[t]{6}{*}{ January } & -3 & 9.6 & 9.9 & 9.0 & 9.2 \\
\hline & -2 & 6.3 & 6.6 & 5.8 & 6.2 \\
\hline & -1 & 4.4 & 4.9 & 4.2 & 4.4 \\
\hline & 1 & -5.1 & -5.6 & -4.5 & -4.8 \\
\hline & 2 & -7.2 & -7.5 & -6.1 & -6.3 \\
\hline & 3 & -9.5 & -9.7 & -9.0 & -9.2 \\
\hline
\end{tabular}


study the effect of intra seasonal variation of temperatures and rainfall on seed cotton yield of both varieties under normal conditions i.e by normal weather data and management practices. Climatic variability was studied by incremental change in the monthly maximum and minimum temperatures from $-3^{\circ} \mathrm{C}$ to $3^{\circ} \mathrm{C}$ during July to January months at $1^{\circ} \mathrm{C}$ interval and rainfall change by $\pm 10, \pm 15$ and \pm 25 per cent during July to September. The simulated seed cotton yields were compared with the mean observed yield and the per cent departure were calculated.

\section{RESULTS AND DISCUSSION}

\section{Seed cotton yield}

The mean observed seed cotton yield of two cultivars of cotton during six years are presented in Table 1. Among different varieties, the maximum seed cotton yield (1014 kg $\mathrm{ha}^{-1}$ ) was observed in Cv. DCH 32 and lowest under cv. G. Cot. Hy. $102\left(882 \mathrm{~kg} \mathrm{ha}^{-1}\right)$. During five years of experimentation, the mean seed cotton yield varied between $1506 \mathrm{~kg} \mathrm{ha}^{-1}$ in 2015-16 to $394 \mathrm{~kg} \mathrm{ha}^{-1}$ in 2012-13 (Table 1).

\section{Calibration and validation}

The observed and simulated seed cotton yield of cotton cultivars during calibration (2011-12 to 2014-15) and validation period (2015-16 and 2016-17) are presented in Fig. 1. The model performance evaluated by test criteria viz. RMSE (72.5), MBE (0.92), MAE (0.92) and PE (8.8) for calibration years indicated close relationship with minimum error. During validation period also the performance of model was quite satisfactory as indicated by the test criteria (RMSE:63.4, MBE:-9.68, MAE:9.68 and PE- 5.2). Hence this model can be used to simulate the tuber yield of different cultivars under different environment.

\section{Effect of temperature variations on varieties}

The effect of increase and/or decrease in maximum and minimum temperatures from $-3^{\circ} \mathrm{C}$ to $+3^{\circ} \mathrm{C}$ in different months on seed cotton yield of two varieties of cotton are presented in Table 3. It is seen that the increase in maximum as well as minimum temperature caused decrease in seed cotton yield in the cultivars, the magnitude varied with the cultivars, as well as the period and the extent of increase in temperature. Overall, the effect of maximum temperature variation was higher $(-13.1$ to $+10.7 \%)$ in $\mathrm{DCH} 32$ than that in G. Cot. Hy. 102 (-12.5 to 10.9\%). The response of change in maximum temperature was higher in December. The change in maximum temperature during September to December had profound influence on seed cotton yield in comparison to other months (Table 3). Kumar et al., (2017) and Singh et al.,
(2008) also reported that increasing daily maximum temperature led to decrease in the yield and similar trend was observed in decreasing maximum temperature increase yield.

The effect of change in minimum temperature on seed cotton yield of both the cultivars was slightly less than that observed with maximum temperature (Table 3 ). The increase in minimum temperature up to $3^{\circ} \mathrm{C}$ had highest $(-12.1 \%)$ yield reduction in cv. DCH 32 followed by -11.8 per cent in G. Cot. Hy. 102. During October to December, the increase in minimum temperature by $3^{\circ} \mathrm{C}$ had highest reduction in seed cotton yield ( -12.5 to $-11.5 \%$ ) of DCH 32 followed by -11.8 to -11.6 per cent reduction in G. Cot. Hy. 102. Thus the cultivar G. Cot. Hy. 102 was less influenced by change in temperatures in comparison to DCH 32.Kumar et al., (2017) also revealed that increase in minimum temperature decreased seed cotton yield.

\section{Effect of rainfall variation on varieties}

The effect of increase and/or decrease in rainfall by $\pm 10, \pm 15$ and \pm 25 per cent in the months of July, August and September on seed cotton yield of two varieties of cotton are presented in Fig. 2. It is seen that the increase in rainfall caused increase in seed cotton yield in both the cultivars, the magnitude varied with the cultivars, as well as the period and the extent of increase rainfall. The variation was highest in the month of September viz. -24.1 to 14.5 per cent in Cv. G. Cot. Hy. 102 and -22.9 to 16.7 per cent in DCH 32 . Rainfall during September month affected most on seed cotton yield in both the varieties followed by August and July months. Cv. DCH 32 was less affected due to rainfall as compared to Cv. G. Cot. Hy. 102 (Fig. 2). Similar results were reported by earlier workers Kumar et al., (2017) and Singh et al. (2008).

\section{CONCLUSION}

The CROPGRO- cotton model of DSSAT family, calibrated and validated for two cultivars of cotton, simulated the seed cotton yield of cotton under different environment satisfactorily with error per cent less than 10 . Hence this model can be used for studying the effect of different environments and management practices on cotton crop in middle Gujarat. The increase and decrease in maximum and minimum temperatures and rainfall had negative/postive impact of seed cotton yield of cotton, the extent of which varied with cultivars and the period/month of temperature change. Overall minimum temperature is found to have less impact on seed cotton yield in all months as compared to maximum temperature. 


\section{AKNOWLEDGEMENT}

This work has been carried out under Emeritus Scientist Scheme of ICAR, the financial support provided is duly acknowledged. Authors are thankful to Anand Agricultural University, Anand for providing the facilities to carry out the work.

\section{REFERENCES}

APTMA. World Cotton and non-Cotton Fibre Consumption. Available online at http://www.aptma.org.pk/ Pak_Textile_Statistics/repo.asp.(2012).

El-Zik, K. M. (1980). The cotton plant- Its growth and development. Western Cotton Prod. Conf. Summary Proc., Fresno, 18-21.

FAS (2014). Oilseeds: World Markets \& Trade. Jan., (2014).

Hodges, H. F., K. R. Reddy, J. M. McKinion and Reddy, V. R. (1993). Temperature effects on cotton. Miss. St. Univ. Exp. Stn. Bulletin 990.

Hoogenboom, G., Jones, J. W., Wilkens, P. W., Porter, C. H., Batchelor, W. D., Hunt, L. A., Boote, K. J., Singh, U., Uryasev, O., Bowen, W. T., Gijsman, A. J., Du Toit, A., White, J. W. E. and Tsuji, G. Y. Decision support system for agro technology transfer: version 4.0. Honolulu: University of Hawaii, 2004.

Hoogenboom, G., Jones, J.W and Boote, K.J. (1992). Modeling growth, development and yield of grain legumes using SOYGRO, PNUTGRO andBEANGRO:AReview. Trans. American Soc. Agric. Eng., 35: 2043- 2056.

Khadi, B. M., Santhy, V and Yadav, M. S. (2010). Highlights the advances in cotton biotechnology, the benefits and socioeconomic impacts. Cotton Biotechnological Advances. Zehr, U.B.(Ed.), XVI. Pp. 245.

Kumar, S. Ram Niwas, Khichar, M. L., Yogesh Kumar, Amit Singh, Premdeep and Abhilash (2017). Sensitivity Analysis of DSSAT CROPGRO-Cotton Model for Cotton under Different Growing Environments. Indian J. Ecol., 44 (Special Issue-4): 237-241.
Monteith, J.L. (1996). The quest for balance in crop modelling. Agron. J., 88: 695-697.

Nagender, T., Raji Reddy, D., Sreenivas, G., Leela Rani, P. Surekha, K. Akhilesh Gupta and Sreekanth, P. D. (2017). Evaluation of CSM-CROPGRO-Cotton Model under Varied.PlantDensitiesand Nitrogen Levels for Simulating Crop Growth, Development and Seed Cotton Yield. Int. Pure App. Biosci., 5 (4): 1738-1754.

Patil, D. D. and Patel, H. R. (2017). Calibration and validation of CROPGRO (DSSAT 4.6) model for chickpea under middle Gujarat agroclimatic region. Int. J. Agril. Sci., 9 (27): 4342- 4344.

PatilD. D., Vyas Pandey,Acharya, R. R. andBaria,L.N. (2018a). Effect of intra-seasonal variation in temperature on tuberyield of potato in middle Gujarat using SUBSTOR model. J. Agrometerol., 20 (1): 22-27.

Patil, D. D., Vyas Pandey, Gurjar Ramesh and Patel, H. P. (2018b). Effect of intra-seasonal variation in temperature and rainfall on seed yield of pigeonpea cultivars using CROPGRO model. J. Agrometerol., 20 (4): 286-292.

Reddy, K. R., Davidonis, G.H., Johnson, A. S. and Vinyard, B. T. (1999).Temperature regime and carbondioxide enrichment alter cotton boll development and fiber properties.Agron J., 91:851-858.

Sandhu, S. S., PrabhjyotKaur, Padmakar,T., Patel, S. R., Rajinder, P., Solanki, N. S., Singh, R. K., Dubey, A. P. and Rao, V. U. M. (2016). Effect of intra-seasonal temperature on wheat at different locations of India: A study using CERES-Wheat model. J. Agrometeorol., 18 (2): 222233.

Singh, M., Kalra, N., Chakraborty, D., Kamble, K., Barman, D., Saha, S., Mittal, R. B. and Pandey, S. (2008). Biophysical and socioeconomic characterization of a water-stressed area and simulating Agriproduction estimates and land use planning undernormal and extremeclimatic events. Environ Monit Assess., 142 (1-3):97-108. 